\title{
Vegetation in karst terrain of southwestern China allocates more biomass to roots
}

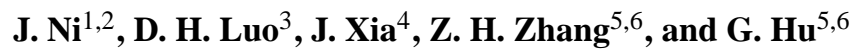 \\ ${ }^{1}$ State Key Laboratory of Environmental Geochemistry, Institute of Geochemistry, Chinese Academy of Sciences, \\ Guiyang, China \\ ${ }^{2}$ Puding Karst Ecosystem Observation and Research Station, Chinese Academy of Sciences, Puding, China \\ ${ }^{3}$ Guizhou Development and Reform Commission, Guiyang, China \\ ${ }^{4}$ Guizhou Forestry Inventory and Planning Institute, Guiyang, China \\ ${ }^{5}$ School of Environment and Life Science, Guangxi Teachers Education University, Nanning, China \\ ${ }^{6}$ Key Laboratory of Beibu Gulf Environment Change and Resources Utilization of Ministry of Education, \\ Guangxi Teachers Education University, Nanning, China
}

Correspondence to: J. Ni (nijian@vip.skleg.cn)

Received: 09 March 2015 - Published in Solid Earth Discuss.: 24 March 2015

Revised: 14 June 2015 - Accepted: 15 June 2015 - Published: 02 July 2015

\begin{abstract}
In mountainous areas of southwestern China, especially Guizhou province, continuous, broadly distributed karst landscapes with harsh and fragile habitats often lead to land degradation. Research indicates that vegetation located in karst terrains has low aboveground biomass and land degradation that reduces vegetation biomass, but belowground biomass measurements are rarely reported. Using the soil pit method, we investigated the root biomass of karst vegetation in five land cover types: grassland, grassscrub tussock, thorn-scrub shrubland, scrub-tree forest, and mixed evergreen and deciduous forest in Maolan, southern Guizhou province, growing in two different soil-rich and rock-dominated habitats. The results show that roots in karst vegetation, especially the coarse roots, and roots in rocky habitats are mostly distributed in the topsoil layers $(89 \%$ on the surface up to $20 \mathrm{~cm}$ depth). The total root biomass in all habitats of all vegetation degradation periods is $18.77 \mathrm{Mg} \mathrm{ha}^{-1}$, in which roots in rocky habitat have higher biomass than in earthy habitat, and coarse root biomass is larger than medium and fine root biomass. The root biomass of mixed evergreen and deciduous forest in karst habitat (35.83 $\mathrm{Mg} \mathrm{ha}^{-1}$ ) is not greater than that of most typical, nonkarst evergreen broad-leaved forests in subtropical regions of China, but the ratio of root to aboveground biomass in karst forest $(0.37)$ is significantly greater than the mean ratio $(0.26 \pm 0.07)$ of subtropical evergreen forests. Vegeta-
\end{abstract}

tion restoration in degraded karst terrain will significantly increase the belowground carbon stock, forming a potential regional carbon sink.

\section{Introduction}

Karst is a highly special geomorphology mainly consisting of limestone and dolomite. This landscape is scattered in many areas worldwide but continuously and widely distributed in southern America, the Mediterranean coasts, and China (Sweeting, 1972). China has approximately 3.44 million $\mathrm{km}^{2}$ of karst areas (buried, covered, and exposed carbonate rock areas), about $36 \%$ of its total land and $15.6 \%$ of all the 22 million $\mathrm{km}^{2}$ karst areas in the world (Jiang et al., 2014). As a country with long-term human disturbances and highspeed economic development, China has suffered strong land use changes and serious land degradation in its entire territory (e.g., Zhang et al., 2007; Bai and Dent, 2009; Zhao et al., 2013). Desertification is therefore a very critical natural and social problem in the dry land and sand land of northern and western China (Ci and Yang, 2010). However, in southern China another desert-like but rock-exposed landscape, the so-called "rocky desertification", becomes another critical environmental disaster (e.g., Wang et al., 2004; Jiang et al., 2014). This is because China has very extensive karst out- 
crops and embeddings in its southwestern political divisions (ca. 0.51 million $\mathrm{km}^{2}, 5.8 \%$ of the total land area), which are close to the Tibetan Plateau in the west and to Burma, Laos, and Vietnam in the south, including Guizhou, Guangxi, Yunnan, Guangdong, Hunan, Hubei, Sichuan, and Chongqing (Jiang et al., 2014), especially in the first three provinces. The dissolutional landforms, caves, and aquifers on soluble rocks create the most beautiful landscapes and tourist resorts. However, they also result in many environmental disasters, such as water pollution, drought, and land degradation of rocky desertification, thereby creating many severe social problems (Zhang et al., 2006; Huang et al., 2008; Bai et al., 2013; Yan and Cai, 2015). Such problems are also common in many other karst regions worldwide, such as the Mediterranean region (Cerdà, 1998) and other European countries (Parise et al., 2009), southern America (Rivera and Aide, 1998), Indian Himalayas (Raizada and Juyal, 2012), and New Zealand (U1rich, 2002).

The fragile karst habitat is vulnerable to human disturbances in southwestern (SW) China. Therefore, forests on karst terrain are easily degraded when the habitat is destroyed by human activity. The bare or less-vegetation-covered karst terrain usually leads to significant rocky desertification, a landscape exhibiting sand desertification in arid Central Asia but covered by big rocks. A total area of ca. 0.11 million $\mathrm{km}^{2}$ of rocky desertification, $22 \%$ of the total land area in SW China, has been reached in year 2000 (Jiang et al., 2014). The rocky desertified land is very difficult to rehabilitate. The completely modified environment, the rock-covered habitat with less soil, and the lack of seed bank in such poor soil make natural restoration of the degraded forests difficult (e.g., Wang et al., 2004; Huang et al., 2008). To rehabilitate the degraded land, we must explore the factors triggering such degradation in geology, hydrology, ecology, and human activities (Jiang et al., 2014) and further the features of restoration processes including changes of aboveground (AGB) and belowground biomass (BGB).

The unique karst morphology produces unique ecosystems in SW China. In subtropical China where the East Asian monsoon brings sufficient rainfall and warm air, forming rich, acidic yellow soils, the representative zonal vegetation is the evergreen broad-leaved forest (ECVC, 1980). In the karst mountainous region of SW China, the typical yet azonal vegetation is the mixed evergreen and deciduous broad-leaved forest growing in alkaline soils. The limestone and dolomite create very harsh habitats and thin but calcic soils. The rainfall in this region is sufficient for plant growth (ca. 1100 to $1300 \mathrm{~cm}$ per year), but the leakage of soil water leads to low species growth, low biomass and productivity of community, and vulnerability of the forest to environmental change. The forest becomes thorn shrubland and dry grassland when degraded, like in other karst regions such as in Spain (Cerdà, 1997) and the Dominican Republic (Izzo et al., 2013). This change is typical outside of the core area of Maolan National Natural Reserve in southern Guizhou province. Studies focus more on changes of community composition and structure in each restoration stage (Yu et al., 2002), but AGB has been rarely measured (Yang and Cheng, 1991; Zhu et al., 1995; Yu et al., 2002) and only one measurement of root biomass (RB) has been reported (Luo et al., 2010).

Roots have important functions in ecosystems worldwide. Roots sustain vegetation, especially forests, and connect the ecological processes of belowground and aboveground through the fluxes of materials and energy (Schenk and Jackson, 2002). RB and productivity are key factors of global and regional carbon cycles (Cairns et al., 1997), especially fine roots (Jackson et al., 1996, 1997; Matamala et al., 2003). Roots can protect soil against erosion. Root architectures (root density, root length density, root diameter, root area ratio, and root distribution) effectively decrease the soil detachment rate, reducing the erodibility of root-permeated saturated top soils in karst mountains (De Baets et al., 2006, 2007a, b).

Roots in karst vegetation, especially in places occupied by rock outcrops, are usually displaced on rock surface and in gaps among rocks where very little soils exist. The harsh habitat in karst terrain makes biomass observations very difficult; only a few biomass measurements in Guizhou province (in most cases, AGB) have been reported thus far (Yang and Cheng, 1991; Tu and Yang, 1995; Zhu et al., 1995; Yu et al., 2002). A mixed evergreen and deciduous broad-leaved forest with $95 \%$ rock outcrop in Maolan of southern Guizhou has an AGB of $89.20 \mathrm{Mg} \mathrm{ha}^{-1}$ in its tree layer, which was measured using the standard tree and harvest method (Yang and Cheng, 1991). Karst forests located in different parts of the mountains have different AGB, but the typical mixed evergreen and deciduous broad-leaved forest has a total AGB of $168.02 \mathrm{Mg} \mathrm{ha}^{-1}$, which is lower than that in other subtropical forests (Zhu et al., 1995). For these two studies, no $\mathrm{RB}$ of trees was measured; only those of understory shrubs and herbs were (Yang and Cheng, 1991). The RB was measured in degraded karst shrublands in central Guizhou (Tu and Yang, 1995), but only values of total RB have been reported and no detailed sampling method can be found. The roots of shrubs were not separated to coarse, medium, and fine roots (Tu and Yang, 1995). A preliminary RB estimation in the forests, scrub-shrublands, and grasslands of Maolan was recently published (Luo et al., 2010), but the number of root samples was very limited (only four samples in each plot) and the RB was possibly not representative.

Research shows that in karst habitat, the AGB of mixed evergreen and deciduous forest is lower than that of zonal subtropical evergreen forest because the rocky habitat with less soil impedes plant growth (Zhu et al., 1995). Preliminary research with very limited root samples indicated that karst vegetation has higher RB than non-karst vegetation in the same bioclimatic zone (Luo et al., 2010). We hypothesize that more biomass allocates to the roots in karst vegetation, but more systematically established plots and sam- 
ples are needed to prove this hypothesis. Therefore, we intensively re-sampled and re-estimated the RB of karst vegetation in Maolan. We considered three aspects of the differences of RB: at various land cover types, at different root diameter classes, and in different edaphic and rocky habitats. The aims of this study are to investigate the RB and its distribution in soil layers in the mountainous karst forest of SW China in order to reveal the roles of RB in specific karst vegetation restoration and in potential carbon stock increment of degraded subtropical China.

\section{Materials and methods}

\subsection{The study area}

The study was conducted in Maolan National Natural Reserve $\left(25^{\circ} 09^{\prime}-25^{\circ} 21^{\prime} \mathrm{N}, 107^{\circ} 52^{\prime}-108^{\circ} 05^{\prime} \mathrm{E}\right)$, located in Libo County of southern Guizhou province, subtropical SW China (Fig. 1). The summer monsoon system brings rich rain water and warm air. The average annual precipitation is $1148 \mathrm{~mm}$ in Libo city $\left(25^{\circ} 25^{\prime} \mathrm{E}, 107^{\circ} 53^{\prime} \mathrm{N}, 428.7 \mathrm{~m}\right)$ and mainly falls from April to October (86\%). The mean annual temperature is $18.3^{\circ} \mathrm{C}$, with the temperature in January at $8.5^{\circ} \mathrm{C}$ and in July at $26.5^{\circ} \mathrm{C}$. The air is humid (relative humidity is $79 \%$ ) and the sky is very cloudy (sunshine percentage is only $24 \%$ ).

The reserve is a typical peak-clump karst depression landscape (a cluster of small peaks with a common base) in a mountainous area covered by limestone and dolomite bedrock and with an altitude ranging from 430 to $1078 \mathrm{~m}$ above sea level (Fig. 1). The exposed rocks are distributed everywhere. The black limestone soil (rendzina in FAO and China's soil taxonomy classifications) is very shallow and discontinuous but rich in nutrients and calcium. However, soil water easily leaks out through the rock lacunas, resulting in a specific drought if sufficient rainfall is absent.

The karst topography, humid and warm monsoon climate, and specific edaphic and rocky microhabitats make the vegetation in this area different from other non-karst subtropical regions. Evergreen trees (accounting for ca. $65 \%$ of total species) mixed with a proportion of deciduous trees $(35 \%)$ in the canopy and sub-canopy layers comprise the typical karst forest, a non-zonal soil climax that is widely distributed in subtropical SW China. Abundant biodiversity and rich rare species can be found in this karst forest (Zhang et al., 2012).

Artificial fire for agriculture and fern picking, goat and cow grazing, and firewood are three major human disturbances in this region, although vegetation within the natural reserve is well protected. The restoration of degraded karst forest can be naturally performed. Such restoration usually passes through five periods, starting from the grassland, moving to grass-scrub tussock, thorn-scrub shrubland, scrubtree forest, and finally to the mixed evergreen and deciduous broad-leaved forest (Yu et al., 2002).
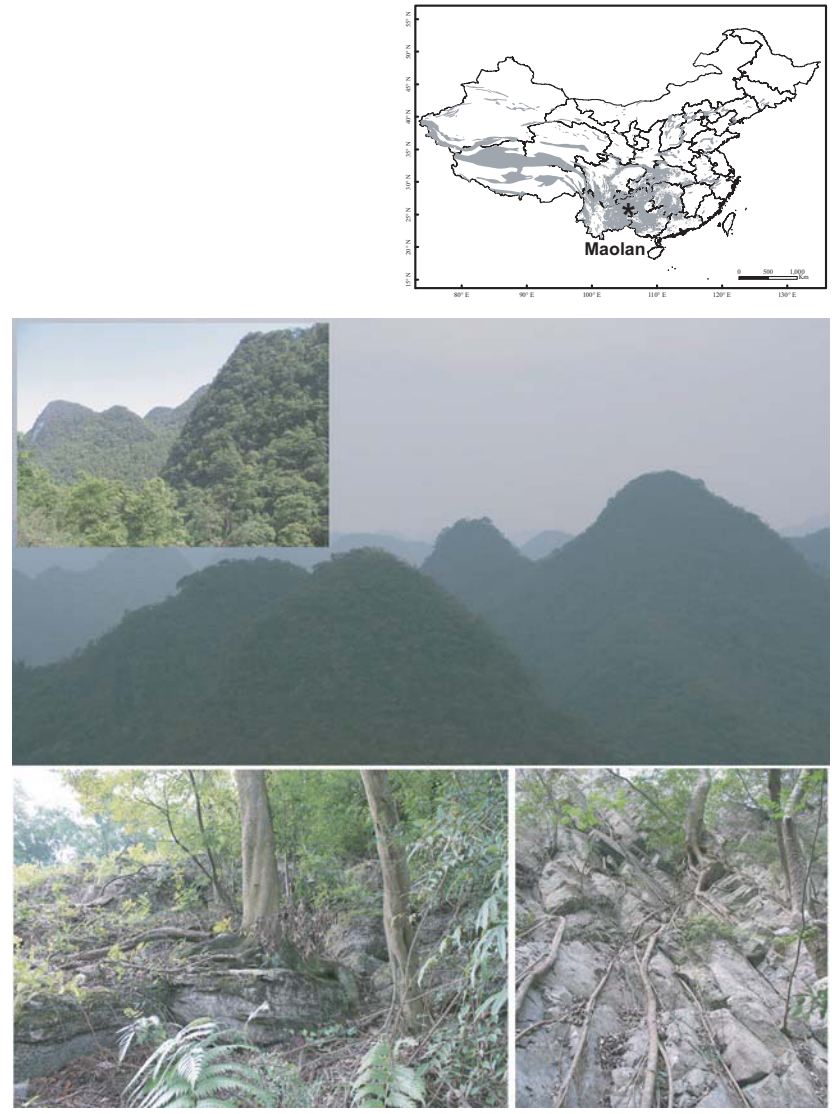

Figure 1. Location of study area in the distribution map of karst terrain in China, and the less-human-disturbed karst peak-clump depression landscape and well-protected mixed evergreen and deciduous broad-leaved forest with roots distributed in rock outcrops in Maolan National Natural Reserve, southern Guizhou province.

\subsection{Root biomass measurements}

Five typical vegetation types representing five land cover types mentioned above were chosen around the Laqiao and Yaogu villages found outside but close to the core area of the Maolan Reserve. Each vegetation type grows in two different soil-rich and rock-dominated habitats. Vegetation was intensively investigated in 10 plots (no replicates for vegetation types), each with a total area of $30 \times 30 \mathrm{~m}^{2}$ for forest, $20 \times 20 \mathrm{~m}^{2}$ for shrubland, $10 \times 10 \mathrm{~m}^{2}$ for scrub tussock, and $5 \times 5 \mathrm{~m}^{2}$ for grassland. Species name, height, diameter at breast height (the basal diameter for small shrubs), and crown range were recorded for woody plants. Species name, height, and coverage were surveyed only for herbaceous plants. The rock outcrop percentage was visually counted and the human disturbance was enquired (Table 1). Normally the grassland is built due to the artificial fire for collecting ferns (as a kind of vegetable) every year. The grass-scrub tussock is subject to heavy or light grazing by goats and cows. The thorn-scrub shrubland is exposed to the light cutoff for firewood. The 
Table 1. Key features of 10 plots for root biomass sampling in Maolan National Natural Reserve, Guizhou province, SW China.

\begin{tabular}{|c|c|c|c|c|c|c|c|c|c|c|c|c|c|c|}
\hline No. & Habitat & $\begin{array}{l}\text { Land } \\
\text { covers }\end{array}$ & Long/lat & $\begin{array}{l}\text { Altitude } \\
(\mathrm{m})\end{array}$ & $\begin{array}{l}\text { Slope } \\
\left({ }^{\circ}\right)\end{array}$ & Aspect & $\begin{array}{l}\text { Dominant } \\
\text { species }\end{array}$ & $\begin{array}{l}\text { Coverage } \\
(\%)\end{array}$ & $\begin{array}{l}\text { DBH } \\
(\mathrm{cm})\end{array}$ & $\begin{array}{l}\text { Height } \\
\text { (m) }\end{array}$ & $\begin{array}{l}\text { Density } \\
\left(\text { No hm }^{-2}\right)\end{array}$ & $\begin{array}{l}\text { Stand age } \\
(\mathrm{yr})\end{array}$ & $\begin{array}{l}\text { Human } \\
\text { disturbance }\end{array}$ & $\begin{array}{l}\text { Rock } \\
\text { outcrop } \\
(\%)\end{array}$ \\
\hline ML-23 & Rock & Grassland & $\begin{array}{l}107^{\circ} 54.293^{\prime}, \\
25^{\circ} 23.634^{\prime}\end{array}$ & 678 & - & - & $\begin{array}{l}\text { Pteridium revo- } \\
\text { lutum, grass }\end{array}$ & - & - & 1.0 & - & 10 & heavy & 40 \\
\hline ML-02 & Rock & $\begin{array}{l}\text { Grass-scrub } \\
\text { tussock }\end{array}$ & $\begin{array}{l}107^{\circ} 55.559^{\prime} \\
25^{\circ} 19.480^{\prime}\end{array}$ & 907 & 35 & SE40 & $\begin{array}{l}\text { Lindera com- } \\
\text { munis, Tirpitzia } \\
\text { sinensis }\end{array}$ & 45 & $1.6(\mathrm{BD})$ & 1.4 & 2020 & $8-12$ & light & 50 \\
\hline ML-06 & Rock & $\begin{array}{l}\text { Thorn-scrub } \\
\text { shrubland }\end{array}$ & $\begin{array}{l}107^{\circ} 55.815^{\prime} \\
25^{\circ} 18.598^{\prime}\end{array}$ & 842 & 35 & SE10 & $\begin{array}{l}\text { Lindera com- } \\
\text { munis, Platy- } \\
\text { carya longipes }\end{array}$ & 55 & 3.8 & 4.0 & 5600 & $12-18$ & very light & 80 \\
\hline ML-13 & Rock & $\begin{array}{l}\text { Scrub-tree } \\
\text { forest }\end{array}$ & $\begin{array}{l}107^{\circ} 57.263^{\prime} \\
25^{\circ} 18.592^{\prime}\end{array}$ & 851 & 40 & WS14 & $\begin{array}{l}\text { Swida aus- } \\
\text { trosinensis, } \\
\text { Clausena } \\
\text { dunniana }\end{array}$ & 65 & 7.8 & 6.8 & 2775 & $60-133$ & no & 80 \\
\hline ML-Q1 & Rock & $\begin{array}{l}\text { Mixed } \\
\text { evergreen- } \\
\text { deciduous } \\
\text { broad-leaved } \\
\text { forest }\end{array}$ & $\begin{array}{l}107^{\circ} 57.483^{\prime} \\
25^{\circ} 18.653^{\prime}\end{array}$ & 860 & 45 & ES & $\begin{array}{l}\text { Clausena } \\
\text { dunniana, } \\
\text { Platycarya } \\
\text { longipes }\end{array}$ & 80 & 8.7 & 7.6 & 2122 & $80-236$ & no & 85 \\
\hline ML-24 & Soil & Grassland & $\begin{array}{l}107^{\circ} 53.777^{\prime} \\
25^{\circ} 23.680^{\prime}\end{array}$ & 647 & - & - & $\begin{array}{l}\text { Pogonatherum } \\
\text { crinitum }\end{array}$ & - & - & 0.2 & - & 0.5 & heavy & 5 \\
\hline ML-04 & Soil & $\begin{array}{l}\text { Grass-scrub } \\
\text { tussock }\end{array}$ & $\begin{array}{l}107^{\circ} 58.018^{\prime} \\
25^{\circ} 18.180^{\prime}\end{array}$ & 743 & 20 & SE30 & $\begin{array}{l}\text { Liquidambar } \\
\text { formosana, } \\
\text { Rhamnus } \\
\text { crenata }\end{array}$ & 85 & 1.5 & 1.0 & 1800 & $8-12$ & light & 5 \\
\hline ML-08 & Soil & $\begin{array}{l}\text { Thorn-scrub } \\
\text { shrubland }\end{array}$ & $\begin{array}{l}107^{\circ} 55.800^{\prime} \\
25^{\circ} 18.610^{\prime}\end{array}$ & 863 & 40 & NW40 & $\begin{array}{l}\text { Lindera } \\
\text { communis, } \\
\text { Pyracantha } \\
\text { atalantioides }\end{array}$ & 50 & 3.9 & 4.1 & 4875 & $13-18$ & very light & 10 \\
\hline ML-12 & Soil & $\begin{array}{l}\text { Scrub-tree } \\
\text { forest }\end{array}$ & $\begin{array}{l}107^{\circ} 57.263^{\prime} \\
25^{\circ} 18.211^{\prime}\end{array}$ & 711 & 30 & $\mathrm{~N}$ & $\begin{array}{l}\text { Swida parvi- } \\
\text { flora, Lindera } \\
\text { communis }\end{array}$ & 75 & 8.6 & 6.9 & 1956 & $25-54$ & no & 10 \\
\hline ML-Q2 & Soil & $\begin{array}{l}\text { Mixed } \\
\text { evergreen- } \\
\text { deciduous } \\
\text { broad-leaved } \\
\text { forest }\end{array}$ & $\begin{array}{l}107^{\circ} 57.350^{\prime} \\
25^{\circ} 18.117^{\prime}\end{array}$ & 925 & 30 & ES, EN & $\begin{array}{l}\text { Ilex ficoidea, } \\
\text { Castanopsis } \\
\text { carlesii var. } \\
\text { spinulosa }\end{array}$ & 75 & 9.6 & 8.2 & 2833 & $60-135$ & no & 20 \\
\hline
\end{tabular}

DBH: diameter at breast height; BD: basal diameter.

scrub-tree forest and the mixed evergreen-deciduous broadleaved forest are faced with light cow grazing.

The roots were sampled from July to September 2009. Measuring RB is time consuming and prone to sampling error, especially in rocky soil (Park et al., 2007). By comparing three different methods of measuring RB (root coring, soil pit, and allometric equation) in six forest stands, Park et al. (2007) found that if the depth and diameter distribution of roots are required, soil pits are the only method allowing characterization of root distribution by depth in rocky soil and can accurately characterize roots up to about $2 \mathrm{~cm}$. Many roots extend for long distances into rock lacuna where few soils exist in the karst terrain (Fig. 1). Some roots can be seen in deep caves, and their lengths are unknown. The huge rock outcrops and steep slopes (normally $30-45^{\circ}$ ) make access to the right sampling place very difficult. A normal root sampling strategy by marking five points an equal distance apart along two diagonals in a quadrat is therefore not possible here. Luo et al. (2010) dug four soil pits around an averaged standard tree in a quadrat to sample the roots, but the spatial representativeness of root samples is not sufficient. An " $S$ " route was roughly set up in this study from the left corner in the lower elevation to the right corner of the upper elevation within each plot. Ten randomly selected soil pits in an area of $50 \times 50 \mathrm{~cm}^{2}$ were each excavated using a shovel along the "S" route. This means that there are five vegetation types in two different habitats (10 vegetation plots) and 10 soil pits in each vegetation plot (100 soil pits in total). Every soil pit was dug at soil layers of $10 \mathrm{~cm}$ interval until no roots were found. If rocks were encountered in multi-ways, we attempted to obtain the soils and roots around rocks and/or in rock gaps, gouges, and troughs. Roots on the rock surface were directly cut down. Roots in any gap among rocks were obtained as completely as possible using different digging, grabbing, and hollowing techniques. All soils and roots were stored in plastic bags and moved to the house in Laqiao village nearby.

Small rocks were removed from the soil samples, and then the soil samples were carefully washed, avoiding the loss of fine roots. All washed roots were air-dried in the room overnight. Roots were classified into three categories based on the root diameter: fine root $(<2 \mathrm{~mm})$, medium root ( 2 to $10 \mathrm{~mm})$, and coarse root $(>10 \mathrm{~mm})$. The roots were stored in envelopes, oven-dried at $80^{\circ} \mathrm{C}$ for $48 \mathrm{~h}$, and weighed. For 
Table 2. Root biomass of karst vegetation in Maolan, southern Guizhou province, SW China.

\begin{tabular}{|c|c|c|c|c|c|c|c|c|}
\hline Root biomass $\left(\mathrm{Mg} \mathrm{ha}^{-1}\right)$ & All habitat & Rocky & Earthy & G & GS & S & $\mathrm{SF}$ & $\mathrm{F}$ \\
\hline Fine root & $1.72 \pm 0.42$ & $1.61 \pm 0.43$ & $1.84 \pm 0.37$ & $1.68 \pm 0.03$ & $1.58 \pm 0.75$ & $1.56 \pm 0.11$ & $1.60 \pm 0.08$ & $2.20 \pm 0.04$ \\
\hline Medium root & $3.54 \pm 1.39$ & $3.87 \pm 1.24$ & $3.22 \pm 1.45$ & $3.40 \pm 2.16$ & $2.18 \pm 0.26$ & $3.68 \pm 0.46$ & $3.37 \pm 0.17$ & $5.09 \pm 0.57$ \\
\hline Coarse root & $13.50 \pm 10.34$ & $13.77 \pm 11.38$ & $13.24 \pm 9.19$ & $0.57 \pm 0.08$ & $8.23 \pm 0.30$ & $8.53 \pm 1.00$ & $21.64 \pm 1.77$ & $28.54 \pm 4.33$ \\
\hline Total & $18.77 \pm 11.14$ & $19.25 \pm 11.66$ & $18.29 \pm 4.79$ & $5.65 \pm 2.28$ & $11.99 \pm 1.32$ & $13.77 \pm 0.43$ & $26.62 \pm 1.85$ & $35.83 \pm 3.72$ \\
\hline
\end{tabular}

G: grassland; GS: grass-scrub tussock; S: thorn-scrub shrubland; SF: scrub-tree forest; F: mixed evergreen and deciduous forest.

roots that were too large to be stored in envelopes, the total dry weight was calculated based on the ratio of fresh to dry materials of small pieces. RB in each plot was averaged according to the measurements of 10 soil pits.

The AGB of all vegetation was estimated (Yuan, 2008) using the allometric functions established by harvesting 30 individuals of 21 standard trees in the same region (Zhu et al., 1995). Such allometric functions took the relationships between biomass of each component (leaf, branch, stem, and all above components) and tree height and diameter at breast height into account, with the correlation coefficients $(R)$ between 0.97 and 0.99 (Zhu et al., 1995). To calculate the ratio of RB to AGB, only the typical, mature mixed evergreen and deciduous broad-leaved forest was exemplified corresponding to typical evergreen broad-leaved forests in the same subtropical zone. All RB and AGB of the latter were obtained by the similar method as the former. The final RB value of the former is an average of RB measured by Luo et al. (2010) and by this study.

Statistical test is performed using the $F$ test (SPSS Inc., 2010) to analyze the significant differences of root biomass in various root types, vegetation types, habitats, and soil depths.

\section{Results}

\subsection{Root distribution}

Roots in vegetation on karst terrain are significantly distributed in the top soil layers (Fig. 2). The first top layer (surface to $10 \mathrm{~cm}$ depth) accounts for $65 \%$ and the second layer $(10$ to $20 \mathrm{~cm}$ ) for $24 \%$ roots. Roots in rocky habitats are more distributed in top $20 \mathrm{~cm}$ (90.7 to $95 \%$ ) than those in earthy habitat ( 86.8 to $90 \%$ ), but this is not significant. Coarse roots occur more slightly (not significantly) in the two top layers $(92.5 \%)$ than medium roots $(89.2 \%)$ and fine roots $(88.8 \%)$. This result is true in both rocky and earthy habitats. However, in rocky habitats, the roots of the three diameter classes in soil depth below $10 \mathrm{~cm}$ are all less than those in earthy habitat. No roots in soil depth between 50 and $60 \mathrm{~cm}$ in rocky habitat were detected and no coarse roots in soil depth between 40 and $60 \mathrm{~cm}$ were observed in both rocky and earthy habitats. The distribution of roots exhibits a similar pattern in different land cover types as the general aforementioned pattern, but all roots in the types of grassland, shrubby grass- land, and scrub shrubland are only distributed in soil depth less than $30 \mathrm{~cm}(<20 \mathrm{~cm}$ in shrubby grassland). The scrubtree forest has fine and medium roots in all layers from soil surface to $60 \mathrm{~cm}$ and coarse roots in soil depths less than $40 \mathrm{~cm}$. The mixed evergreen-deciduous broad-leaved forest only has roots at depths less than $40 \mathrm{~cm}$.

\subsection{Root biomass}

The total $\mathrm{RB}$ in all habitats of all vegetation types is $18.77 \mathrm{Mg} \mathrm{ha}^{-1}$. The coarse roots have the largest biomass compared with those of medium and fine roots. The total RB in rocky habitat is slightly higher than that in earthy habitat. The coarse and medium roots have the same trend as the total, but the fine roots have a slightly higher biomass in earthy habitats than in rocky habitats (Table 2). During the vegetation restoration from grassland to mixed evergreendeciduous broad-leaved forest, the total RB significantly increases by ca. 7 -fold. The coarse roots significantly increase their biomass from grassland to grass-scrub and shrubland (16-fold), and then increase again to shrub-forest and forest (2.5-fold to 3.4-fold). The medium and fine roots have changeable biomass in different land cover types. Although the climax (mixed evergreen-deciduous broad-leaved forest) has the highest values among all land covers, the pioneer type (grassland) does not have the lowest values of fine and medium roots (Table 2). The climax forest in rocky habitat has the total RB of $39.55 \mathrm{Mg} \mathrm{ha}^{-1}$, whereas in earthy habitat it has a lower $\mathrm{RB}$ of $32.10 \mathrm{Mg} \mathrm{ha}^{-1}$.

Consistent with the root distribution (Fig. 2), the RB distribution has a similar pattern in different soil layers (Fig. 3). RB mostly concentrates on the surface up to $10 \mathrm{~cm}$ soil depth, accounting for $85.6 \%$ of total RB in all habitats. In 10 to $20 \mathrm{~cm}$ soil depth, only $12.6 \%$ of total RB is distributed; very few total RB occurs in soil layer $>20 \mathrm{~cm}$. The coarse roots have the highest biomass in each soil layer above $40 \mathrm{~cm}$, following the medium and fine roots (Fig. 3a). This pattern also exists in rocky (Fig. 3b) and earthy habitats (Fig. 3c), except that coarse roots at 20 to $40 \mathrm{~cm}$ depth in rocky habitat have less biomass than medium roots (Fig. 3b). The biomass of coarse and medium roots in rocky habitat is higher than that in earthy habitat at soil depth $<10 \mathrm{~cm}$, but the fine roots have slightly less biomass in rocky habitats than in earthy habitats (Fig. $3 \mathrm{~b}$ and c). At $10 \mathrm{~cm}$ to $20 \mathrm{~cm}$ soil depth, coarse roots have less biomass in rocky habitats than in earthy habitats, 

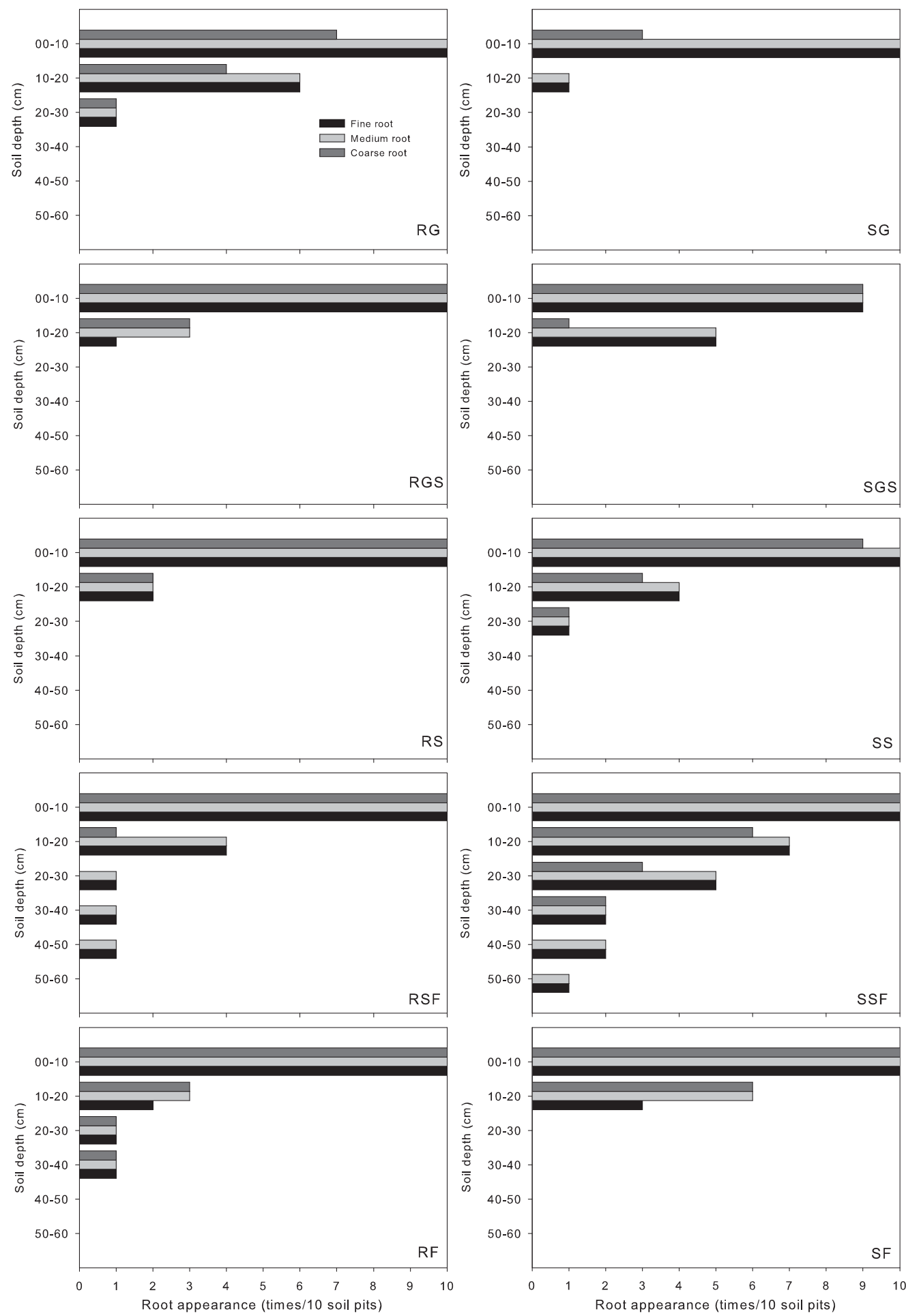

Figure 2. Frequency of root appearance in soil layers. Note that the total number of plots for root biomass sampling is 10 in each vegetation type. A value of 10 indicates that roots occur in this soil layer in all 10 plots. A value of 0 indicates that no roots occurred in this soil layer in all 10 plots. RG: rock-dominated grassland; SG: soil-rich grassland; RGS: rock-dominated grass-scrub tussock; SGS: soil-rich grass-scrub tussock; RS: rock-dominated thorn-scrub shrubland; SS: soil-rich thorn-scrub shrubland; RSF: rock-dominated scrub-tree forest; SSF: soilrich scrub-tree forest; RF: rock-dominated mixed evergreen and deciduous forest; SF: soil-rich mixed evergreen and deciduous forest. 


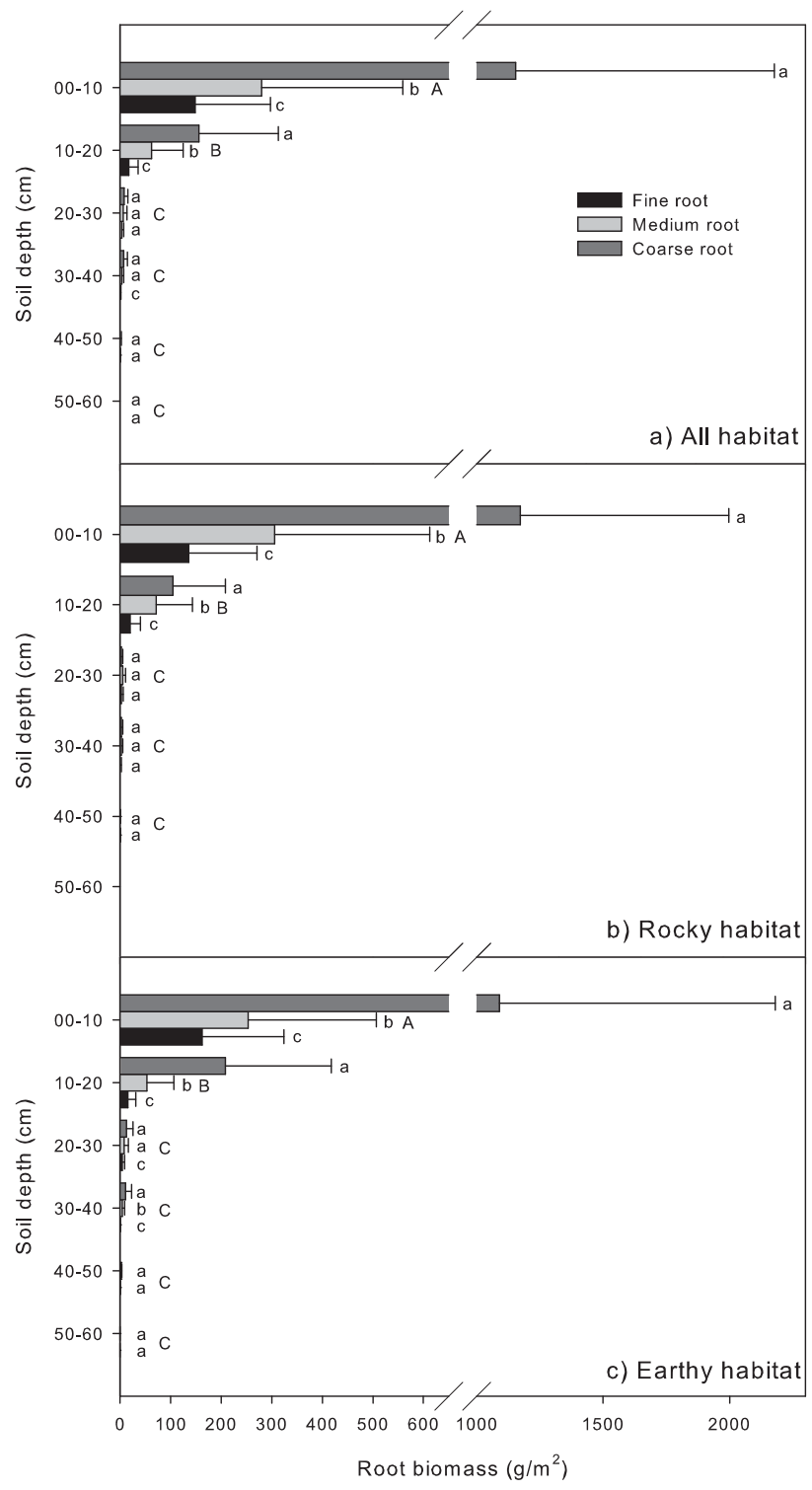

Figure 3. Root biomass in different habitats: (a) all habitats; (b) rocky habitat; (c) earthy habitat. The same letters above the error bars denote no significant differences and different letters denote significant differences. The lower cases are for various root diameter classes and the upper cases for various soil depths.

but other roots have the opposite trend. At depth of 20 to $40 \mathrm{~cm}$, all roots (except for fine roots at 30 to $40 \mathrm{~cm}$ ) in rocky habitat have less biomass than in earthy habitat (Fig. $3 \mathrm{~b}$ and c).

On average, the total $\mathrm{RB}$ at soil surface to $10 \mathrm{~cm}$ increases from grassland to forest climax, but the difference between grass-scrub and scrub shrublands is not significant (Fig. 4a). At 10 to $20 \mathrm{~cm}$, the total $\mathrm{RB}$ in grassland is higher than in grass-scrub shrubland and slightly higher than in scrub shrubland. At other depths, the scrub-tree forest always has higher total RB than the mixed forest (Fig. 4a). How- ever, roots in different diameter classes have very different biomasses in each land cover type (Fig. 4b-d). Forest climax has the highest RB in any diameter class from the surface up to $20 \mathrm{~cm}$ soil depth compared with other land cover types, except for medium root in grassland at 10 to $20 \mathrm{~cm}$ depth. Scrub-tree forest, scrub, and grass-scrub shrublands have intermediate RB at each layer, but their trends are changeable for different diameter classes. However, grassland shows higher fine RB at soil depth $<10 \mathrm{~cm}$ than scrub-tree forest and shrubland (Fig. 4b). Grassland has higher medium RB at the first soil layer than grass-scrub shrubland and scrub-tree forest, and the highest medium RB at depth of 10 to $20 \mathrm{~cm}$ among all types (Fig. 4c). Coarse RB in grassland is the lowest (Fig. 4d). The scrub-tree forest has the highest RB (in all diameters) in other soil layers less than $20 \mathrm{~cm}$ (Fig . 4b-d).

\section{Discussion}

\subsection{Uncertainties of root biomass measurements on karst terrain}

As mentioned above, accessing to a right place to sample roots in karst terrain is quite difficult because of the very steep slope, sharp and large extended outcrops, and extremely high heterogeneity of soil distribution (very few in some places and often distributed among outcrop gaps). The commonly used root sampling methods, namely root coring and soil pit sampling, have to be modified in rocky soils (Park et al., 2007). The random selection of sampling sites is impossible on karst terrain. A site with general characteristics of the common habitat in a plot has to be subjectively chosen.

Roots on outcrop surfaces are easily cut, but obtaining all of the roots on the surface is difficult because some roots extend to long distances or to very deep soils or both. Roots distributed in very deep soil and rock gaps are very hard to obtain, possibly underestimating the RB in karst vegetation. Distinguishing the root and root sprout of several shrubs and small trees is also difficult. Both roots and root sprouts were harvested in this study, likely resulting in overestimated RB. Furthermore, coarser roots are encountered too rarely to be estimated by the method of soil pits (Park et al., 2007), resulting in an underestimate of coarse roots. In addition, the difficulty of sampling leads to insufficient root plot areas and inadequate duplicates for statistics. Although RB in this region was sampled using a similar method (Luo et al., 2010), the number of root samples was highly limited (only four soil columns in each vegetation type). Thus, this study is the first to comprehensively measure RB in karst vegetation of SW China.

Soils in karst terrain have extraordinary heterogenetic distribution, both vertically and horizontally (e.g., Wang et al., 2007). This distribution is ascribed to rock outcrops that are distributed everywhere and huge rocks that are embedded in deep underground. Soils are very shallow and tiny on the 
Table 3. Root biomass (RB) and the ratio of RB to aboveground biomass (AGB) of typical evergreen broad-leaved forests in subtropical China.

\begin{tabular}{|c|c|c|c|c|c|c|c|c|}
\hline Region & Site & Location & Forest type & Age (yr) & $\mathrm{RB}\left(\mathrm{Mg} \mathrm{ha}^{-1}\right)$ & $\operatorname{AGB}\left(\mathrm{Mg} \mathrm{ha}^{-1}\right)$ & $\mathrm{RB} / \mathrm{AGB}$ & References \\
\hline \multicolumn{9}{|c|}{ Eastern subtropical } \\
\hline & Tiantong & $\begin{array}{l}121^{\circ} 47^{\prime} \mathrm{E} \\
29^{\circ} 48^{\prime} \mathrm{N} \\
260 \mathrm{~m}\end{array}$ & $\begin{array}{l}\text { Schima superba, } \\
\text { Castanopsis } \\
\text { carlesii }\end{array}$ & 52 & 49.09 & 171.33 & 0.29 & $\begin{array}{l}\text { Yang et al. } \\
(2010)\end{array}$ \\
\hline & Hangzhou & $\begin{array}{l}120^{\circ} 10^{\prime} \mathrm{E}, \\
30^{\circ} 15^{\prime} \mathrm{N}\end{array}$ & $\begin{array}{l}\text { Schima superba, } \\
\text { Castanopsis } \\
\text { carlesii }\end{array}$ & $32-39$ & 31.97 & 94.68 & 0.34 & Yu et al. (1993) \\
\hline & Jiande & $\begin{array}{l}119^{\circ} 31^{\prime} \mathrm{E}, \\
29^{\circ} 24^{\prime} \mathrm{N}, \\
190-230 \mathrm{~m}\end{array}$ & $\begin{array}{l}\text { Cyclobalanopsis } \\
\text { glauca }\end{array}$ & $30-35$ & 25.50 & 85.77 & 0.30 & Chen (1993) \\
\hline & Minqing & $\begin{array}{l}118^{\circ} 40^{\prime} \mathrm{E} \\
26^{\circ} 15^{\prime} \mathrm{N}\end{array}$ & $\begin{array}{l}\text { Cyclobalanopsis } \\
\text { chungii }\end{array}$ & 35 & 83.83 & 303.80 & 0.28 & Huang (2006) \\
\hline & Wuyi Mt. & $\begin{array}{l}117^{\circ} 41^{\prime} \mathrm{E} \\
27^{\circ} 42^{\prime} \mathrm{N} \\
120 \mathrm{~m}\end{array}$ & Castanopsis eyrei & 51 & 56.46 & 350.82 & 0.16 & Lin et al. (1996) \\
\hline & Dinghu Mt. & $\begin{array}{l}112^{\circ} 35^{\prime} \mathrm{E} \\
23^{\circ} 10^{\prime} \mathrm{N} \\
200 \mathrm{~m}\end{array}$ & $\begin{array}{l}\text { Crypyocarya } \\
\text { concina, Schima } \\
\text { superba, Machilus } \\
\text { chinensis }\end{array}$ & 400 & 38.18 & 170.20 & 0.22 & $\begin{array}{l}\text { Zhang and } \\
\text { Ding (1996) }\end{array}$ \\
\hline & Dinghu Mt. & $\begin{array}{l}112^{\circ} 35^{\prime} \mathrm{E} \\
23^{\circ} 10^{\prime} \mathrm{N} \\
200 \mathrm{~m}\end{array}$ & $\begin{array}{l}\text { Castanopsis } \\
\text { chinensis, Crypy- } \\
\text { ocarya concina }\end{array}$ & 400 & 51.77 & 243.87 & 0.21 & $\begin{array}{l}\text { Wen et al. } \\
\text { (1997) }\end{array}$ \\
\hline & Dinghu Mt. & $\begin{array}{l}112^{\circ} 35^{\prime} \mathrm{E} \\
23^{\circ} 10^{\prime} \mathrm{N} \\
200 \mathrm{~m}\end{array}$ & $\begin{array}{l}\text { Erythrophleum } \\
\text { fordii }\end{array}$ & - & 81.50 & 486.67 & 0.17 & Yi et al. (2000) \\
\hline & Huitong & $\begin{array}{l}109^{\circ} 30^{\prime} \mathrm{E}, \\
26^{\circ} 48^{\prime} \mathrm{N}\end{array}$ & $\begin{array}{l}\text { Engelhardia rox- } \\
\text { burghiana, Schima } \\
\text { superba, Cyclobal- } \\
\text { anopsis glauca }\end{array}$ & 33 & 23.52 & 132.90 & 0.18 & Sun (2005) \\
\hline & Maolan & $\begin{array}{l}107^{\circ} 57^{\prime} \mathrm{E} \\
25^{\circ} 18^{\prime} \mathrm{N} \\
860-925 \mathrm{~m}\end{array}$ & $\begin{array}{l}\text { Castanopsis car- } \\
\text { lesii var. spinulosa, } \\
\text { Clausena dunni- } \\
\text { ana, Platycarya } \\
\text { longipes }\end{array}$ & $60-236$ & 46.99 & 125.77 & 0.37 & $\begin{array}{l}\text { This study; Zhu } \\
\text { et al. (1995); } \\
\text { Yuan (2008); } \\
\text { Luo et al. } \\
\text { (2010) }\end{array}$ \\
\hline \multicolumn{9}{|c|}{ Western subtropical } \\
\hline & Fumin & $\begin{array}{l}103^{\circ} 33^{\prime} \mathrm{E} \\
25^{\circ} 19^{\prime} \mathrm{N} \\
2300 \mathrm{~m}\end{array}$ & $\begin{array}{l}\text { Cyclobalanopsis } \\
\text { delavayi }\end{array}$ & 20 & 34.29 & 96.28 & 0.36 & $\begin{array}{l}\text { Dang et al. } \\
\text { (1994) }\end{array}$ \\
\hline & Songming & $\begin{array}{l}102^{\circ} 45^{\prime} \mathrm{E} \\
25^{\circ} 24^{\prime} \mathrm{N} \\
2300 \mathrm{~m}\end{array}$ & $\begin{array}{l}\text { Castanopsis } \\
\text { orthacantha }\end{array}$ & - & 60.06 & 200.75 & 0.30 & $\begin{array}{l}\text { Dang and Wu } \\
\text { (1994) }\end{array}$ \\
\hline & Ailao Mt. & $\begin{array}{l}101^{\circ} 25^{\prime} \mathrm{E} \\
24^{\circ} 10^{\prime} \mathrm{N} \\
2400-2600 \mathrm{~m}\end{array}$ & $\begin{array}{l}\text { Lithocarpus } \\
\text { xylocarpus }\end{array}$ & $166-325$ & 106.67 & 287.44 & 0.37 & $\begin{array}{l}\text { Xie et al. } \\
(1996) ; \text { Liu et } \\
\text { al. (2002) }\end{array}$ \\
\hline & Pu'er & $\begin{array}{l}100^{\circ} 51^{\prime} \mathrm{E} \\
23^{\circ} 12^{\prime} \mathrm{N}\end{array}$ & $\begin{array}{l}\text { Castanopsis } \\
\text { echidnocarpa }\end{array}$ & $12-42$ & 24.34 & 100.85 & 0.24 & $\begin{array}{l}\text { Dang and Wu } \\
\text { (1992) }\end{array}$ \\
\hline
\end{tabular}



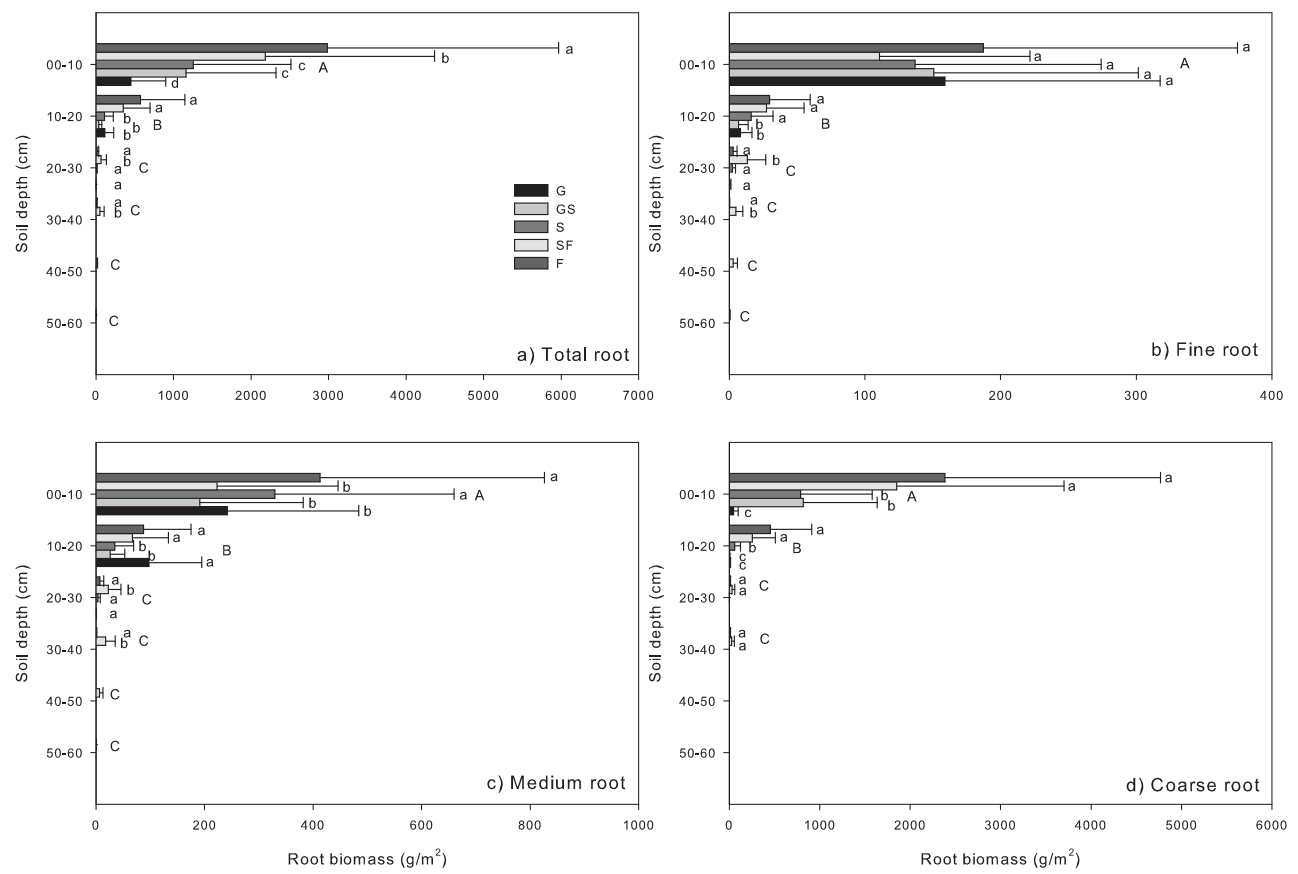

Figure 4. Root biomass in different land cover types: (a) total roots; (b) fine roots; (c) medium roots; and (d) coarse roots. F: mixed evergreen and deciduous forest; SF: scrub-tree forest; S: thorn-scrub shrubland; GS: grass-scrub tussock; G: grassland. The same letters above the error bars denote no significant differences and different letters denote significant differences. The lower cases are for various land cover types and the upper cases for various soil depths.

surface ground and unevenly, discontinuously distributed in deep underground. Therefore, root distribution is vertically and horizontally chaotic. Some roots are distributed on the surface ground and rock surface, some in long-distance rock gaps, and some in very deep rock gaps, even chiseling in deep belowground caves. Such heterogeneities of soil and root distributions result in a need of more soil and root samples to represent sufficiently the root distribution and to fulfill the statistical requirements. Ten soil pits with highly limited volume are insufficient, i.e., the RB in Maolan in this study is possibly underestimated. A greater number and largersized supplementary soil pits obtained via sampling using soil drilling equipment are needed. A better way is to set up grid points in $2-5 \mathrm{~m}$ intervals among grids.

The peak-clump depression is only one of the eight karst morphological types in SW China. The RB measurement is only a representative of vegetation in this kind of karst landscape. Other karst morphological types, such as the plateau surface type in central Guizhou province, the gorge type in the west, the trough valley type in the north, the fault basin in northeastern Yunnan province, and the peak-forest and plain type in northeastern Guangxi autonomous region, all need their own RB measurements to characterize their belowground features of local and regional vegetation.

\subsection{Comparison with subtropical forests}

The globally averaged root distribution for temperate and tropical forest ecosystems was approximately $60 \%$ of roots in the top $30 \mathrm{~cm}$, estimated based on a soil depth of $2 \mathrm{~m}$ (Jackson et al., 1996). However, in karst ecosystems the soil depth is mostly $50-60 \mathrm{~cm}$ only and ca. $95 \%$ of roots are distributed in the top $30 \mathrm{~cm}$. A key reason is that most of roots, especially the coarse roots, must be allocated in the top soils to support the shoot to be firmly fixed in the harsh karst habitat. Similarly, ca. $98 \%$ of RB is in the top $20 \mathrm{~cm}$ soils in karst ecosystem, whereas ca. $50-70 \%$ of RB is allocated in the top $30 \mathrm{~cm}$ soils in world's temperate and tropical forests (Jackson et al., 1996).

Studies of mixed evergreen-deciduous forests at different habitats in Maolan (Yang and Cheng, 1991; Zhu et al., 1995) and of scrubs in central Guizhou province (Tu and Yang, 1995) show that karst vegetation has lower AGB than other typical evergreen broad-leaved forests in subtropical China. A preliminary study indicated that RB in karst vegetation is not lower than that of either broad-leaved or needle-leaved forests in subtropical China (Luo et al., 2010). The present study with more number of root samples further confirmed this finding, showing that our hypothesis of more biomass in karst vegetation being allocated to roots is true. However, it is not the RB in karst forest always significantly greater than 
that of typical evergreen forests, whereas it is the ratio of $\mathrm{RB}$ to AGB.

The RB of mixed evergreen and deciduous broad-leaved forest in Maolan is only greater than half of measurements of typical evergreen broad-leaved forests in subtropical regions (Table 3). The average RB in eastern (49.09 $\mathrm{Mg} \mathrm{ha}^{-1}$ ) and western $\left(59.37 \mathrm{Mg} \mathrm{ha}^{-1}\right)$ subtropical regions are both higher than that of karst forest based on Luo et al. (2010) and this study $\left(46.99 \mathrm{Mg} \mathrm{ha}^{-1}\right)$. However, the ratio of root to shoot in karst forest (0.37) is similar to and almost greater than the ratio of evergreen forests in the east (0.16-0.34) and in the west (0.24-0.37). In the world's boreal, temperate, and tropical forest ecosystems the averaged root/shoot ratio (Jackson et al., 1996) is $0.25(0.18-0.34)$. This difference is due to the suitable non-karst habitat favoring AGB accumulation and the harsh karst habitat favoring BGB. Plants growing in tiny, shallow soils and rocky habitats tend to allocate more resources to roots to maintain and physically support the ecosystem. However, dominant canopy tree species in karst forests have low net photosynthetic rate and low light photosynthetic productivity (Yang, 2011), but changes of hydraulic conductivity of deep tree roots may help the trees maintain the use of reliable water resources from depth (McElrone et al., 2007). Such ecophysiological evidences imply that karst forests have lower growth rate and lower biomass and productivity, but in such a shallow-water lacking environment more roots are developed to elevate deeper groundwater.

\subsection{Implications for land rehabilitation and carbon increment}

The harsh karst habitat is fragile. The root is the only physical support of woody plants in the tiny soil, rocky, and heterogenetic habitat and is the only tissue that can absorb deep underground (river) water. The harsh karst landscape makes the degraded forest difficult to be restored to its original condition. After the disturbances of firewood cutting, fire, and grazing in Maolan area, karst vegetation can be more rapidly restored to scrub shrubland and woodland in 5 to 10 years because of its more rainfall and soils and less interference of human activities. However, in Guanling area of central Guizhou province, the cutting of the original karst forest in the late 1950s completely modified the local habitat, making the restoration of the original vegetation impossible for at least 50 years. This effect is ascribed to the extremely strong human-land contradiction in the plateau surface region of central Guizhou province. Before the 1950s, the karst region of the entire Guizhou province was mostly covered by forests, but in the 1980s to the 1990s, rocky desertification accelerated after karst forest degradation and heavy soil erosion (Zhang et al., 2006). In the 1990s to the 2000s, largearea and high-intensity afforestation slowly minimized rocky desertification, but complete control of the rocky desertification and improvement of local economy of the poor areas are still very difficult tasks. Therefore, an urgent need exists to protect the current karst forests, to restore the degraded vegetation, and to improve the quality of life of locals.

The area of scrub land (ca. $62.57 \times 10^{3} \mathrm{~km}^{2}$ ) and tussock and grassland $\left(29.68 \times 10^{3} \mathrm{~km}^{2}\right)$ accounts for $52.5 \%$ of the total vegetation area in Guizhou (ECVMC, 2007). If this degraded land is converted into forested land, which currently only occupies ca. $23.7 \%$ of the total vegetation area, the biomass carbon stock in Guizhou province could increase significantly by 3-4 fold in aboveground and 4-7 fold in belowground. This is a great potential carbon sink for mitigating regional climate warming in the future.

\section{Conclusions}

Root biomass of vegetation is reduced in different land cover types from forest to scrub shrubland and tussock grassland. The ratio of root to aboveground biomass in karst forest is greater than that of evergreen forests in the subtropical China. This confirmed that plants growing in tiny, shallow soils and rocky habitat of karst terrain tend to allocate more resources to roots in order to maintain and physically support the ecosystem. However, due to the extraordinary heterogenetic distributions of soils and roots in karst terrain and the difficulty in access to every root in deep underground, root biomass might be underestimated in this study. More and larger-area soil and root samples are needed in future study.

Acknowledgements. The study was supported by the National Basic Research Program of China (2013CB956704), the Hundred Talents Program of the Chinese Academy of Sciences (2011031), and the Science and Technique Foundation of Guizhou province (GKH-J-2012-2332). We thank Daigui Zhang, Jiedong Zhu, Jingcheng Ran, Luming Wei, Huanbai Xia, and Weilian Yu for their support in the field studies.

Edited by: A. Cerdà

\section{References}

Bai, Z. and Dent, D.: Recent land degradation and improvement in China, Ambio, 38, 150-156, 2009.

Bai, X. Y., Wang, S. J., and Xiong, K. N.: Assessing spatialtemporal evolution processes of karst rocky desertification land: indications for restoration strategies, Land Degrad. Dev., 24, 47$56,2013$.

Cairns, M. A., Brown, S., Helme, E. H., and Baumgardner, G. A.: Root biomass allocation in the world's upland forests, Oecologia, 111, 1-11, 1997.

Cerdà, A.: Seasonal changes of the infiltration rates in a typical Mediterranean scrubland on limestone in southeast Spain, J. Hydrol., 198, 198-209, 1997.

Cerdà, A.: Relationship between climate and soil hydrological and erosional characteristics along climatic gradients in Mediterranean limestone areas, Geomorphology, 25, 123-134, 1998. 
Chen, Q. C.: Study on the Net Primary Production of Cyclobalanopsis glauca Forest, Hangzhou University Press, Hangzhou, 319 pp., 1993 (in Chinese).

Ci, L. J. and Yang, X. H.: Desertification and Its Control in China, Higher Education Press, Beijing, and Springer-Verlag, Berlin Heidelberg, 513 pp., 2010.

Dang, C. L. and Wu, Z. L.: Studies on the biomass for Castanopsis echidnocarpa community of monsoon evergreen broadleaved forest, Journal of Yunnan University (Natural Science), 14, 95107, 1992 (in Chinese).

Dang, C. L. and Wu, Z. L.: Studies on the biomass of Castanopsis orthacantha community, Journal of Yunnan University (Natural Science), 16, 195-199, 1994 (in Chinese).

Dang, C. L., Wu, Z. L., and Zhang, Z.: Studies on the biomass of Cyclobalanopsis delavayi community, Journal of Yunnan University (Natural Science), 16, 205-209, 1994 (in Chinese).

De Baets, S., Poesen, J., Gyssels, G., and Knapen, A.: Effects of grass roots on the erodibility of topsoils during concentrated flow, Geomorphology, 76, 54-67, 2006.

De Baets, S., Poesen, J., Knapen, A., Barbera, G. G., and Navarro, J. A.: Root characteristics of representative Mediterranean plant species and their erosion-reducing potential during concentrated runoff, Plant and Soil, 29, 169-183, 2007a.

De Baets, S., Poesen, J., Knapen, A., and Galindo, P.: Impact of root architecture on the erosion-reducing potential of roots during concentrated flow, Earth Surf. Proc. Land., 32, 1323-1345, 2007b.

Editorial Committee for Vegetation of China (ECVC): Vegetation of China, Science Press, Beijing, 1375 pp., 1980 (in Chinese).

Editorial Committee of Vegetation Map of the People's Republic of China (ECVMC), Chinese Academy of Sciences: Vegetation Map of the People's Republic of China (1:1000 000), Geology Press, Xi'an, 2007 (in Chinese).

Huang, D. Z.: Biomass characteristics of secondary forest community of Cyclobalanopsis chungii in the lower Minjiang River, Protection Forest Science and Technology, 70, 16-18, 2006 (in Chinese).

Huang, Q. H., Cai, Y. L., and Xing, X. S.: Rocky desertification, antidesertification, and sustainable development in the karst mountain region of Southwest China, Ambio, 37, 390-392, 2008.

Izzo, M., Araujo, N., Aucelli, P. P. C., Maratea, A., and Sánchez, A.: Land sensitivity to desertification in the Dominican Republic: an adaptation of the ESA methodology, Land Degrad. Dev., 24, 486-449, 2013.

Jackson, R. B., Canadell, J., Ehleringer, J. R., Mooney, H. A., Sala, O. E., and Schulze, E. D.: A global analysis of root distribution for terrestrial biomes, Oecologia, 108, 389-411, 1996.

Jackson, R. B., Mooney, H. A., and Schulze, E. D.: A global budget for fine root biomass, surface area, and nutrient contents, P. Natl. Acad. Sci. USA, 94, 7362-7366, 1997.

Jiang, Z. C., Lian, Y. Q., and Qin, X. Q.: Rocky desertification in Southwest China: Impacts, causes, and restoration, Earth-Sci. Rev., 132, 1-12, 2014.

Lin, Y. M., Lin, P., Li, Z. J., He, J. Y., and Liu, C. D.: Biomass and productivity of Castanopsis eyrei community in Wuyi Mountains, Journal of Xiamen University (Natural Science), 35, 269 275, 1996 (in Chinese).

Liu, W. Y., Fox, J. E. D., and Xu, Z. F.: Biomass and nutrient accumulation in montane evergreen broad-leaved forest (Lithocarpus xylocarpus type) in Ailao Mountains, SW China, Forest Ecol. Manage., 158, 223-235, 2002.

Luo, D. H., Xia, J., Yuan, J. W., Zhang, Z. H., Zhu, J. D., and Ni, J.: Root biomass of karst vegetation in a mountainous area of southwestern China, Chinese J. Plant Ecol., 34, 611-618, 2010 (in Chinese).

Matamala, R., Gonzàlez-Meler, M. A., Jastrow, J. D., Norby, R. J., and Schlesinger, W. H.: Impacts of fine root turnover on forest NPP and soil C sequestration potential, Science, 302, 13851387, 2003.

McElrone, A. J., Bichler, J., Pockman, W. T., Addington, R. N., Linder, C. R., and Jackson, R. B.: Aquaporin-mediated changes of hydraulic conductivity of deep tree roots accessed via caves, Plant Cell Environ., 30, 1411-1421, 2007.

Parise, M., De Waele, J., and Gutierrez, F.: Current perspectives on the environmental impacts and hazards in karst, Environ. Geol., 58, 235-237, 2009.

Park, B. B., Yanai, R. D., Vadeboncoeur, M. A., and Hamburg, S. P.: Estimating root biomass in rocky soils using pits, cores, and allometric equations, Soil Sci. Soc. Am. J., 71, 206-213, 2007.

Raizada, A. and Juyal, G. P.: Tree species diversity, species regeneration and biological productivity of seeded Acacia catechu Willd. in rehabilitated limestone mines in the North West Indian Himalayas, Land Degrad. Dev., 23, 167-174, 2012.

Rivera, L. W. and Aide, T. M.: Forest recovery in the karst region of Puerto Rico, Forest Ecol. Manage., 108, 63-75, 1998.

Schenk, H. J. and Jackson, R. B.: Rooting depths, lateral root spreads and below-ground/above-ground allometries of plants in water-limited ecosystems, J. Ecol., 90, 480-494, 2002.

Sun, H. L.: Ecosystems of China, Science Press, Beijing, 1822 pp., 2005 (in Chinese).

Sweeting, M. M.: Karst Landforms, Macmillan, London, 362 pp., 1972.

Tu, Y. L. and Yang, J.: Study on biomass of the karst scrub communities in central region of Guizhou Province, Carsologica Sinica, 14, 199-207, 1995 (in Chinese).

Urich, P. B.: Land Use in Karst Terrain: Review of Impacts of Primary Activities on Temperate Karst Ecosystems. New Zealand Department of Conservation, Wellington, 60 pp., 2002.

Wang, S. J., Liu, Q. M., and Zhang, D. F.: Karst rocky desertification in southwestern China: geomorphology, land use, impact and rehabilitation, Land Degrad. Dev., 15, 115-121, 2004.

Wang, S. J., Lu, H. M., Zhou, Y. C., Xie, L. P., and Xiao, D. A.: Spatial variability of soil organic carbon and representative soil sampling method in Maolan karst virgin forest, Acta Pedologica Sinica, 44, 475-483, 2007 (in Chinese).

Wen, D. Z., Wei, P., Kong, G. H., Zhang, Q. M., and Huang, Z. L.: Biomass study of the community of Castanopsis chinensis + Cryptocarya concinna + Schima superba in Dinghu Mt., a southern China Reserve, Acta Ecologica Sinica, 17, 497-504, 1997 (in Chinese).

Xie, S. C., Liu, W. Y., Li, S. C., and Yang, G. P.: Preliminary studies on the biomass of middle mountain moist evergreen broadleaved forests in Ailao Mountain, Yunnan, Acta Phytoecologica Sinica, 20, 167-176, 1996 (in Chinese).

Yan, X. and Cai, Y. L.: Multi-scale anthropogenic driving forces of karst rocky desertification in southwest China, Land Degrad. Dev., 26, 193-200, 2015. 
Yang, H. K. and Cheng, S. Z.: Study on biomass of the karst forest community in Maolan, Guizhou Province, Acta Ecologica Sinica, 11, 307-312, 1991 (in Chinese).

Yang, R.: Canopy Structure and Dynamics of Degraded Karst Forest, $\mathrm{PhD}$ Thesis, Guizhou University, Guiyang, 100 pp., 2011 (in Chinese).

Yang, T. H., Song, K., Da, L. J., Li, X. P., and Wu, J. P.: The biomass and aboveground net primary productivity of Schima superbaCastanopsis carlesii forest in East China, Science China Life Science, 53, 811-821, 2010 (in Chinese).

Yi, W. M., Zhang, Z. P., Ding, M. M., and Wang, B. S.: Biomass and efficiency of radiation utilization in Erythrophleum fordii community, Acta Ecologica Sinica, 20, 397-403, 2000 (in Chinese).

Yu, L. F., Zhu, S. Q., Ye, J. Z., Wei, L. M., and Chen, Z. R.: Dynamics of a degraded karst forest in the process of natural restoration, Scientia Silvae Sinica, 38, 1-7, 2002 (in Chinese).

Yu, Y. W., Shi, D. F., Jiang, Q. Y., He, L. M., and Chen, G. R.: On the biomass of secondary Schima superba forest in Hangzhou, Journal of Zhejiang Forestry College, 10, 157-161, 1993 (in Chinese).

Yuan, J. W.: Comparison of composition and Biomass of Karst Vegetation at Different Stages of Rocky Desertification in Guizhou Province, SW China. Master Thesis, Institute of Botany, Chinese Academy of Sciences, Beijing, 53 pp., 2008 (in Chinese).
Zhang, B. P., Xiao, F., Wu, H. Z., Mo, S. G., Zhu, S. Q., Yu, L. F., Xiong, K. N., and Lan A. J.: Combating the fragile karst environment in Guizhou, China, Ambio, 35, 94-96, 2006.

Zhang, Z. H., Hu, G., Zhu, J. D., and Ni, J.: Stand structure, woody species richness and composition of subtropical karst forests in Maolan, south-west China, Journal of Tropical Forest Science, 24, 498-506, 2012.

Zhang, Z. P. and Ding, M. M.: Biomass and efficiency of radiation utilization in monsoon evergreen broadleaved forest in Dinghushan Biosphere Reserve, Acta Ecologica Sinica, 16, 525534, 1996 (in Chinese).

Zhang, K., Yu, Z., Li, X., Zhou, W., and Zhang, D.: Land use change and land degradation in China from 1991 to 2001, Land Degrad. Dev., 18, 209-219, 2007.

Zhao, G., Mu, X., Wen, Z., Wang, F., and Gao, P.: Soil erosion, conservation, and Eco-environment changes in the Loess Plateau of China, Land Degrad. Dev., 24, 499-510, 2013.

Zhu, S. Q., Wei, L. M., Chen, Z. R., and Zhang, C. G.: A preliminary study on biomass components of Karst forest in Maolan of Guizhou Province, China, Acta Phytoecologica Sinica, 19, 358367, 1995 (in Chinese). 